brain cells of rats killed at various times after birth. Our work reinforces these suggestions.

This work was supported by the SEITA.

Department of Biochemistry and Enzymology, Pierre Lesca Institut Gustave Roussy, 94 Villejuif, France.

Received May 20; revised August 15, 1968. ${ }^{1}$ Curtis, P. J., Burdon, M. G., and Smellie, R. M. S., Biochem. J., 98, 813

${ }^{2}$ Curtis, P. J., and Smellie, R. M. S., Biochem. J., 98, 818 (1966).

3 Lesca, P., CR Acad. Sci. Paris, 266, 27 (1968).

4 Laskowski, M., Adv. Enzymol., 29, 165 (1967).

${ }^{5}$ Lehman, I, R., Ann. Rev. Biochem., 36, 645 (1967).

"Chauveau, J., Moule, Y., and Rouiller, C., Exp. Cell. Res.,11, 31 ' (1956).

' le Duve, C., Wattiaux, R., and Baudhuin, P., Adv. Enzymology, 24, 291 (1962).

"Smith, L, in Metkods of Biochemical Analysis, 2, 427 (edit. by Glick, D.) (Interscience, New York, 1955).

'Goutier, R., and Leonard, A., Exp. Cell. Res., 28, 335 (1962).

\section{Metabolism of 'Propham' (Isopropyl N-phenylcarbamate) in the Rat}

Several $N$-phenylcarbamates are currently used as selective pre and postemergent herbicides to control weeds in agronomic crops. Much is known of the fate of the $N$-phenylcarbamates in soils where micro-organisms play an important part in their decomposition ${ }^{\mathbf{1}, 2}$, and their metabolism has also been studied in plants ${ }^{3-5}$. Although these compounds are relatively non-persistent ${ }^{6}$ their fate on ingestion by mammals is of major significance in estimating safe limits for residues in food? Toxicological studies on 'Propham' and 'Chloropropham' have boen undertaken using the mouse, rat, pig, dog and rabbit $^{8}$, but no work has been done on their mammalian metabolism.

The simplest of these $N$-phenylcarbamates is 'Propham' (IPC or isopropyl $N$-phenylcarbamate). We have examined the metabolism of 'Propham' in the rat and identified a major urinary metabolite as the sulphate of isopropyl $N$-p -hydroxyphenylcarbamate.

The $24 \mathrm{~h}$ urine obtained from rats which had received $30 \mathrm{mg}$ of 'Propham' intraperitoneally in ethanol $(0.4 \mathrm{ml}$.) was successively extracted with heptane, then ether, and was then saturated with salt and extracted with ethanolic ether $(1: 1)$. Thin-layer chromatograms of the extracts and their hydrolysates were compared with those obtained using extracts of urine from rats which had received only ethanol $(0.4 \mathrm{ml}$.) intraperitoneally. Using rhodamine B and short wavelength ultraviolet light $(253.7 \mathrm{~m} \mu)$ for visualization, a metabolite was detected in the ethanolic ether extract. The metabolite gave negative tests for phenols and primary aromatic amines using ferric ferricyanide solution and Ehrlich reagent respectively. Hydrolysis with $\mathrm{N}$ hydrochloric acid at $100^{\circ} \mathrm{C}$ for $2 \mathrm{~h}$ or with limpet sulphatase type III (Sigma) at $37^{\circ} \mathrm{C}$ for $17 \mathrm{~h}$ gave a different spot on thin-layer chromatography, which gave a positive phenol test but a negative amine test. No such spot occurred when bacterial $\beta$-glucuronidase was used for hydrolysis. That the carbamate link was stable in these acidic conditions was confirmed by identical treatment of 'Propham'. No aniline could be detected and recovery of 'Propham' was virtually quantitative.

The hydrolysed metabolite was converted to $p$-aminophenol by refluxing in $4 \mathrm{~N}$ hydrochloric acid for $2 \mathrm{~h}$. This was identified by cochromatography with an authentic sample and reactions with chromogenic reagents. Thus the hydrolysed metabolite was identified as isopropyl $N$ - $p$-hydroxyphenyl carbamate and the metabolite itself was identified as the $O$-sulphate of isopropyl $N$-p-hydroxyphenylcarbamate.

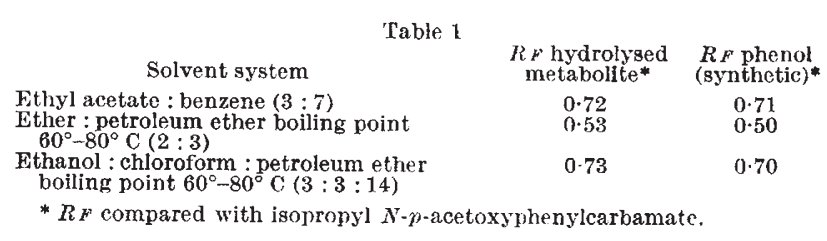

Confirmation of the identity of the hydrolysed metabolite was achieved by its synthesis. $p$-Acetoxybenzoylazide, prepared from $p$-acetoxybenzoyl chloride and sodium azide, was rearranged (Curtius rearrangement) to $p$-acetoxyphenylisocyanate. The latter was not isolated, but was treated directly with isopropanol to yield isopropyl $N$ - $p$-acetoxyphenylcarbamate, melting point $135^{\circ}-$ $136.5^{\circ} \mathrm{C}$. Mild hydrolysis with sodium bicarbonate in methanol afforded the phenol isopropyl $N$ - $p$-hydroxyphenylcarbamate, melting point $98^{\circ}-99^{\circ} \mathrm{C}$. (Baskakov and Mel'nikov ${ }^{9}$ report melting point $112^{\circ} \mathrm{C}$ for the phenol.) The structures of the acetate and phenol were confirmed by their infrared and nuclear magnetic resonance spectra, and by elemental analysis. The phenol and hydrolysed metabolite behaved identically in three thin-layer chromatography systems (Table 1).

The metabolism of 'Propham' is unexpectedly simple. No hydrolysis appears to take place in vivo, for no metabolites with free or conjugated amino groups were found. 'Propham' itself resists acid hydrolysis. In view of the stability of the carbamate it would not have been surprising if oxidation had occurred in the isopropyl group, for alkyl oxidation frequently takes place more readily than aryl hydroxylation in molecules containing both groupings. But only a phenolic metabolite with an intact isopropyl group was found. Hydroxylation of the aromatic ring in the para position is in agreement with the known pattern of such biotransformations in the rat.

This work was supported by a grant from the Australian Meat Research Committee.

G. M. Holder

A. J. RYAN

Department of Pharmacy,

University of Sydney.

Received May 16; revised June 17, 1968.

1 Kaufman, D. D., J. Agric. Food Chem., 15, 582 (1967).

' Kaufman, D. D., and Kearney, P. C., Appl. Microbiol., 13, 443 (1965).

${ }^{3}$ Baskakov, Yu. A., Zaschita Rastenii ot Vreditelei $i$ Boleznei, 6 (7), 34 (1961), through Chem. Abst., 56, 1796d (1962).

'Riden, J. R., and Hopkins, T. R., J. Agric, Food Chem., 10, 455 (1962).

${ }^{5}$ Chin, Wei Tsung, Stanovick, R. P., Cullen, T. E., and Holsing, G. C., Weeds, 12, $201(1964)$.

- DeRose, H. R., Bot. Gaz., 107, 583 (1946).

Traluations of the Toxicity of Pesticide Residues in Food (FAO/WHO, Rome, 1964).

Evaluations of the Toxicity of Pesticide Residues in Food, 125, 129 (FAO/ WHO, Rome, 1964).

${ }^{8}$ Baskakov, Yu. A., and Mel'nikov, N. N., Khim. Nauka i Prom., 3, 683 (1958), through (Yhem. Abst., 58, 7062i (1959).

\section{Tremorgenic Toxin from Penicillium cyclopium grown on Food Materials}

Drugs and other compounds capable of causing sustained trembling are rare; in a survey of ten thousand compounds Everett et al. found less than ten with this property". One of the best known is tremorine (1,4-dipyrrolidine2 -butyne) which is converted into a more active compound, oxotremorine, by body tissues. Various synthetic amino alcohols also stimulate prolonged tremors, but their mechanism of action differs from that of tremorine and other more familiar compounds ${ }^{3}$.

Wilson and Wilson previously described a tremorgenconvulsant ${ }^{4}$ as a metabolite of Aspergillus flavus, a common soil fungus which produces several other toxic compounds including aflatoxins ${ }^{5}$. In subsequent, unpublished work a microcrystalline preparation of the toxin was isolated from extracts and found to have a molecular 